\title{
Erratum Notice of Author Affiliation Correction Point-of-Care Airway Ultrasonography Prior to an Emergency Cricothyroidotomy Case report
}

$$
\begin{aligned}
& \text { تصحيح لعنوان كاتب مقال } \\
& \text { نقطة الرعاية للمسلك الهوائي بتخطيط الصدى قبل عملية بضع الغشاء الحلقي الدرقي الطارئة } \\
& \text { تقرير حالة }
\end{aligned}
$$

NOTICE OF ERRATUM FOR: IQHBAL ET AL. POINT-OF-CARE AIRWAY ULTRASONOGRAPHY PRIOR TO AN EMERGENCY CRICOTHYROIDOTOMY: CASE REPORT. SULTAN QABOOS UNIV MED J 2018; 18:E219-22. HTTPS://DOI.ORG/10.18295/SQUMJ.2018.18.02.017.

The Editors of Sultan Qaboos University Medical Journal (SQUMJ) have been informed that the authors of an article by Iqhbal et al. in the May 2018 issue of SQUMJ wish to make a correction to the affiliation details of the authors of the above article. ${ }^{1}$

The first and corresponding author, Mohamad Iqhbal, contacted SQUMJ in January 2019 notifying the editors of a mistake in the spelling of the institution in the authors' affiliation details: Department of Emergency Medicine, Faculty of Medicine, MARA University of Technology, Selangor, Malaysia. However, this correction could not be made as the article had already been published several months previously. ${ }^{1}$ For the reasons stated herein, the Editors of SQUMJ wish to notify readers that the affiliation details of the authors for the above article are changed to the following: Department of Emergency Medicine, Faculty of Medicine, Universiti Teknologi MARA, Selangor, Malaysia.

The corresponding author takes sole responsibility for this notice and would like to apologise to the readers, reviewers and editors of SQUMJ for this correction made after publication.

\section{References}

1. Iqhbal M, Noor JM, Karim NA, Ismail I, Sanib H, Mokhtar MA, et al. Point-of-care airway ultrasonography prior to an emergency cricothyroidotomy: Case report. Sultan Qaboos Univ Med J 2018; 18:e219-22. https://doi.org/10.18295/squmj.2018.18.02.017. 